\title{
Bioassays prove the suitability of mining debris mixed with sewage sludge for land reclamation purposes
}

\author{
Xavier Domene • Stefania Mattana • Wilson Ramírez • \\ Joan Colón · Patrícia Jiménez · Teresa Balanyà • \\ Josep M. Alcañiz $\cdot$ Manel Bonmatí
}

Received: 5 December 2008 / Accepted: 27 February 2009/Published online: 24 March 2009

(C) Springer-Verlag 2009

\begin{abstract}
Background, aim, and scope Mining activities disturb land and reduce its capacity to support a complete functional ecosystem. Reclamation activities in this case are not easy due to the large amount of soil required. This is why mining debris are usually used as surrogate of soil, despite their unsuitable physicochemical properties. However, these properties can be improved with the amendment using an organic source, usually sewage sludge. Nevertheless, the use of sludge might lead to impacts on soil and water ecosystems because of its physicochemical properties and pollutant content. The aim of this study is to assess the suitability of the use of mining debris amended with sewage sludge as practice for the reclamation of land degraded by limestone-quarrying activities.

Materials and methods Two different types of mining debris from the same limestone quarry and six different types of composted or thermally dried sewage sludge were studied. A laboratory assessment was carried out by means of standardized bioassays of sludges, together with a field assessment carried out in lysimeters filled with debris-sludge mixtures.
\end{abstract}

Responsible editor: Joop Vegter

X. Domene $(\bowtie) \cdot S$. Mattana $\cdot$ W. Ramírez $\cdot J$. Colón $\cdot$

J. M. Alcañiz

Center for Ecological Research and Forestry Applications - CREAF,

Facultat de Biociències, Universitat Autònoma de Barcelona,

Cerdanyola del Vallès,

08193 Barcelona, Spain

e-mail: x.domene@creaf.uab.es

P. Jiménez $\cdot \mathrm{T}$. Balanyà $\cdot \mathrm{M}$. Bonmatí

Escola Superior d'Agricultura de Barcelona (ESAB),

Universitat Politècnica de Catalunya, UPC Campus Baix Llobregat,

Av. Canal Olímpic s.n.,

08860 Castelldefels, Spain
The field assessment was carried out using both the soil-waste mixtures, amended with dosages similar to those used for restoration purposes and their corresponding leachates. The variation of physicochemical properties and the outcomes of different bioassays (soil microorganisms biomass and respiration, enzymatic activities, plant emergence and growth, collembolan survival and reproduction, and the Microtox assay) were used as indicators of fertilizing or ecotoxicological effects.

Results The mining debris used in our study showed a poor capacity for biological recovery, as shown by the lower biological outcomes measured in control lysimeters compared to lysimeters amended with sludge. The addition of sludge improved debris just before the sludge application in terms of its physicochemical and biological properties (microorganism's biomass, respiration and enzymatic activities) which, in some cases, persisted after a year. Conversely, in some sludges, an inhibition in soil collembolans was observed just before the amendment, but any inhibitory effect disappeared after a year. Concerning the leachates obtained from field lysimeters after a week and a year, no inhibitory effects were detectable for aquatic bacteria.

Discussion The effects observed on some of the measured biological endpoints, both in laboratory and field assays, were mainly mediated by physicochemical parameters related to a low stability of organic matter, but in the opposite sense depending on the organism considered. Microbial parameters were enhanced when the organic matter added had a low stability (high content in labile organic matter) but, on the other hand, collembolan performance was negatively affected. The lack of toxicity of leachates indicates a low risk for groundwaters of this reclamation practice.

Conclusions The results of this study support the use of mining debris mixed with sludge for land reclamation of 
degraded land by quarrying. The addition of sludge allowed a quick plant cover re-establishment and provided a suitable habitat for soil biota because no long-term ecotoxicological risks were observed neither for soils nor groundwaters. The results also indicate that the environmental risk of sludges might be reduced using sludges with a high content in stable organic matter.

Recommendations and perspectives The use of mining debris mixed with sewage sludges for mining reclamation purposes is suitable since long-term ecotoxicological risks were not observed. In addition, the results support the suitability of bioassays for the prediction of the success or risk of specific land reclamation practices in order to avoid unsuccessful attempts.

Keywords Ecotoxicity tests · Land reclamation .

Quarrying · Sewage sludge · Soil microorganisms · Soil fauna

\section{Background, aim, and scope}

Since the Spanish reclamation law in 1982 (Real Decreto 2994/1982), the Spanish Government and the autonomous regional authorities have passed several legislative initiatives which obligate quarry owners to reclaim unused areas before they can receive authorization to exploit new areas. This legislation has led to a large amount of research into the best practices to achieve suitable restoration with the lowest cost for the quarry owners.

Mining seriously disturbs land and not only reduces its capacity to support vegetation but also to sustain a complete functional ecosystem. This inability is the result of several factors such as steep topography, which leads to excessive erosion, the unsuitable physical properties of mining debris (stony and sandy substrates with poor waterholding capacity and CEC, or clayey soils with poor infiltration, permeability and drainage), inadequate chemical properties (extreme $\mathrm{pH}$, heavy metal contents), low nutrient and organic matter contents, and reduced biological activity (US EPA 1995; Sort and Alcañiz 1996).

For all these reasons, in recent years, local authorities have encouraged the use of sewage sludge in land reclamation given the increasing production of this material due to the enactment of the European Directive on Wastewater Treatment (Council Directive 91/271/EEC). The use of sewage sludge as a soil conditioner for restoration is a cheap and suitable option. The addition of sludge not only results in quick plant cover growth due to the nutrients added, but also in an improvement in soil structure, thereby protecting the soil from erosion (Sort and Alcañiz 1996). In addition, the use of sludge or other organic wastes buffers the $\mathrm{pH}$ (US EPA 1995) and reduces metal leachability (Brown et al. 2003; Alvarenga et al.
2008). Equally important, the addition of organic wastes enhances the activities of microorganisms (Ros et al. 2003; Jiménez et al. 2007) and soil fauna communities (Andrés 1999; Al-Assiuty et al. 2000; Barrera et al. 2001; Piearce et al. 2003) which, together with plants, play a key role in achieving a successfully restored habitat (Neher 1999).

Sewage sludge is commonly used in the restoration of degraded lands because of its recognized benefits in terms of soil fertility. Several studies have shown its suitability in land reclamation, and it is generally added in a single application and at much higher application rates than those used in agriculture. It is especially useful in soils in the Mediterranean region, with their intrinsic low organic matter content, where the re-establishment of natural plant cover is difficult due to the dry climate (Ros et al. 2003). However, the lack of legislation regulating the application of organic matter for reclamation purposes may result in the application of unsuitable sludges or the use of too high dosages leading to an impact on soil and water ecosystems. Its physicochemical properties and pollutant content may directly impair the role of soil as a life habitat and its ecological functions (Andrés and Domene 2005; Domene et al. 2008), and indirectly impact groundwater and surrounding stream waters by means of leaching and runoff processes.

This study assesses the benefits and the potential ecotoxicological risks of the use of six different sewage sludges for the restoration of land degraded by limestonequarrying activities. On the one hand, the benefits and risks of sludges were compared in laboratory conditions using several ecotoxicological standardized protocols. The benefits and risks were also assessed in field conditions by means of lysimeters placed outdoors for a year and containing soil amended with dosages similar to those used for restoration purposes. The assessment was carried out using both the soil-waste mixtures and their corresponding leachates. For this purpose, soil microorganisms and their enzymatic activities, several plant species, the soil collembolan Folsomia candida, and the aquatic bacteria Vibrio fischeri were used as indicator organisms.

\section{Materials and methods}

\subsection{Experimental site and debris used}

The study was carried out in a limestone quarry located in Begues (Barcelona, Spain). The quarry faces south-east and has a typical Mediterranean climate (altitude $=375 \mathrm{~m}$, mean annual precipitation $=644 \mathrm{~mm}$, mean annual temperature $=$ $13^{\circ} \mathrm{C}$ ). Accumulated precipitation during the period of the experiment (May 2005-June 2006) was $628.5 \mathrm{~mm}$ and, therefore, close to the mean annual precipitation for this site (SMC, Meteorological Service of Catalonia). 
The quarry produces limestone and gravel for construction purposes. Two main types of final debris are produced: extraction debris (obtained during limestone extraction and composed of soil, marl, and colluvial deposits) and trituration debris (obtained from the mechanical crushing of limestone to produce gravels). Both types of debris were studied as substrates for land reclamation.

The two debris types which are the subject of this study displayed clearly different compositions. Trituration debris contained more coarse fragments, sand, and calcium carbonate contents than extraction debris. Both types of debris displayed a highly basic $\mathrm{pH}$ and low nutrient levels (Table 1).

\subsection{Sewage sludges}

The sludges came from six different wastewater treatments plants (WWTP) and were collected in the winter of 2005 and stored in a cold chamber $\left(5^{\circ} \mathrm{C}\right)$ until used. In the majority of these plants, anaerobic digestion and mechanical dewatering of the sludge were carried out prior to posttreatments, obtaining what is known as dewatered sludge. However, one of the plants did not carry out any treatment to the raw dewatered sludge before the post-treatments (Besòs). The dewatered or raw sludge obtained subsequently underwent different treatments followed by post-treatments in order to achieve a higher degree of hygienization and a reduction in water content. More precisely, three of the WWTP carried out composting as a post-treatment, while the remainder performed thermal drying (Table 2). The composting process varied somewhat in the different plants. As a general rule, the thermophilic phase lasted between 15 and 28 days, while the maturation phase was always carried out in pile for 2-3 months. Thermal drying also differed from one plant to another, but was always carried out in a heated rotary cylinder with injected hot air at a temperature of between $80^{\circ} \mathrm{C}$ and $90^{\circ} \mathrm{C}$.

The composted sludges displayed a typical granular appearance and contained a significant fraction of bulking agent (wood chips in CBLA and CVIL, pine bark and spent coffee grounds in CMAN), while the thermally dried sludges clearly differed in appearance given their diverse origin and the drying processes they had undergone: dusty in TMAT, fibrous in TBES, and in the form of spherical pellets in TSAB (around $1 \mathrm{~cm}$ ).
The sludges were used in their original form in the field toxicity assays with lysimeters. However, in the laboratory toxicity assessment, they were specially prepared for the assays. More precisely, the sludges were dried at $60^{\circ} \mathrm{C}$ for $48 \mathrm{~h}$ and then ground and sieved to $2 \mathrm{~mm}$ to ensure the homogeneity of the sample and the accuracy of the lower concentrations tested. The physicochemical properties of the different sludges together with the pollutant burden are shown in Table 3, and refer to the sludge samples dried for the ecotoxicological assays.

Dry matter, $\mathrm{pH}$, electrical conductivity, total organic matter, and total nitrogen were measured according to EN 12880 (2000), EN 13037 (1999), EN 13038 (1999), EN 12879 (2000), and EN 13342 (2000), respectively. Nonhydrolyzable (stable) organic matter and non-hydrolyzable nitrogen corresponded to the percentage of organic matter and nitrogen remaining as residue after acid hydrolysis of the sludge sample, as described in the standard method of the Ministère de l'Agriculture de Belgique (1971). In this method, $1.5 \mathrm{~g}$ of oven dried sludge is hydrolyzed with $10 \mathrm{ml}$ of sulfuric acid (72\%) at room temperature for $3 \mathrm{~h}$. Then, the mixture is diluted with distilled water to 400 and gently boiled under reflux for $5 \mathrm{~h}$, then cooled and filtered. Then, the residue is washed with distilled water and dried $\left(105^{\circ} \mathrm{C}\right)$, and organic matter content is determined by calcination at $560^{\circ} \mathrm{C}$ for $3 \mathrm{~h}$. Non-hydrolyzable nitrogen was also assessed by the Kjeldahl method from this residue. This acid hydrolysis removes the more labile fraction of an organic substrate, which consists mainly of polysaccharides and proteins.

Ammonium $\left(\mathrm{NH}_{4}^{+}\right)$was measured from sludge solution distillates, but as the sludge solution was obtained from the dried sample, they might not be representative of the original values in the fresh sample. However, these ammonium values were taken into account because sludges were dried previous to their use in the bioassays. Nitrate $\left(\mathrm{NO}_{3}{ }^{-}\right)$was measured by high performance liquid chromatography-ion chromatography (HPLC-IC) from an extract obtained as follows: a 5-g sample dried at $105^{\circ} \mathrm{C}$ for $24 \mathrm{~h}$ was extracted in $50 \mathrm{ml}$ of ultrapure water and ultrasounded for $1 \mathrm{~h}$. Subsequently, a known volume of supernatant was collected and filtered through a $0.45-\mu \mathrm{m}$ nylon syringe filter, obtaining the extract used for HPLC-IC. When necessary, extracts were diluted. $\mathrm{P}_{2} \mathrm{O}_{5}$ and $\mathrm{K}_{2} \mathrm{O}$ analysis was carried out according to the Bray-Kurtz method and flame photometry,

Table 1 Texture, calcium carbonate content, $\mathrm{pH}$, and nutrients of the debris studied

\begin{tabular}{lcccccccccc}
\hline Debris type & Coarse elements (\%) & Sand (\%) & Silt (\%) & Clay (\%) & $\mathrm{CaCO}_{3}(\%)$ & $\mathrm{pH}$ & $\left.\mathrm{EC} \mathrm{(dS} \mathrm{m}{ }^{-1}\right)$ & $\mathrm{C}(\%)$ & $\mathrm{N}(\%)$ & $\mathrm{P}(\%)$ \\
\hline Extraction & 61.9 & 42.5 & 37.0 & 20.4 & 39.3 & 8.5 & 0.47 & 0.51 & 0.06 & 5.8 \\
Trituration & 86.0 & 54.8 & 22.6 & 22.4 & 63.6 & 8.9 & 0.20 & 0.25 & 0.05 & 5.8 \\
\hline
\end{tabular}

Coarse elements $(>2 \mathrm{~mm})$, sand $(2-0.05 \mathrm{~mm})$, silt $(0.05-0.002 \mathrm{~mm})$, clay $(<0.002 \mathrm{~mm})$ 
Table 2 Origin, treatments, and post-treatments of the sludges

\begin{tabular}{llll}
\hline Sludge & WWTP & Treatment & Post-treatment \\
\hline CBLA & Blanes & Anaerobic digestion, dewatering & Composting in closed tunnel \\
CMAN & Manresa & Anaerobic digestion, dewatering & Composting in open heap \\
CVIL & Vila-seca/Salou & Aerobic digestion, dewatering & Composting in closed tunnel \\
TBES & Besòs & Dewatering & Thermal drying \\
TMAT & Mataró & Anaerobic digestion, dewatering & Thermal drying \\
TSAB & Sabadell & Anaerobic digestion, dewatering & Thermal drying \\
\hline
\end{tabular}

respectively. Elementary analysis of $\mathrm{Cd}, \mathrm{Cr}, \mathrm{Cu}, \mathrm{Ni}, \mathrm{Pb}$, and $\mathrm{Zn}$ was carried out by ICP-MS in accordance with ISO Guideline 11885 (ISO 1996).

Ethoxylated nonylphenols (NPE) were measured with HRGC-HRMS, polychlorinated biphenyls (PCB) by HRGC-ECD, while linear alkylbenzene sulfonates (LAS) were determined by HPLC with UV detectors. The values for each pollutant group were expressed as indicated in the third draft of the Working Document on Sludge (European Commission 2000): LAS represent total values, NPE corresponds to the sum of concentrations of nonylphenol (NP) and nonylphenol ethoxylates with one (NPEO1) or two ethoxy groups (NPEO2), while PCB is the sum of the polychlorinated biphenyl congeners number 28, 52, 101, $118,138,153$, and 180.

\subsection{Laboratory toxicity assessment}

The direct toxicity of sludges was determined in the laboratory in order to assess the relative toxicities of sludges prior to their use in field conditions, since amendment rates used in the field experiment were not strictly comparable because they were based on the organic matter content of each sludge and debris type (see next paragraph). In the laboratory, the toxicity of sludge-soil mixtures together with sludge elutriates was tested in order to estimate their potential environmental toxicity for exposed soil and aquatic organisms (potentially exposed after leaching or runoff from the amended soil).

Sludge elutriate toxicity was assessed with the Microtox assay, in accordance with ISO Guideline 11348-3 (ISO
Table 3 Physicochemical properties and heavy metal and organic pollutant contents of the sludges
See Table 2 for sludge abbreviations

nd non-detectable levels

\begin{tabular}{|c|c|c|c|c|c|c|}
\hline Sludge properties & CBLA & CMAN & CVIL & TBES & TMAT & TSAB \\
\hline Dry matter $(\%)$ & 69.8 & 61.5 & 65.1 & 85.6 & 88.5 & 90.8 \\
\hline $\mathrm{pH}$ & 6.48 & 7.10 & 6.91 & 6.13 & 6.17 & 7.28 \\
\hline $\mathrm{CE}(\mathrm{dS} / \mathrm{m})$ & 7.59 & 3.86 & 8.48 & 1.39 & 5.84 & 0.86 \\
\hline Organic matter (\%) & 56.6 & 55.5 & 58.3 & 72.3 & 74.0 & 62.2 \\
\hline Stable organic matter $(\%)$ & 29.0 & 40.6 & 35.8 & 8.55 & 40.4 & 39.5 \\
\hline N (\%) & 3.20 & 2.25 & 2.98 & 2.22 & 3.52 & 3.86 \\
\hline Non-hydrolyzable N (\%) & 0.76 & 0.90 & 1.01 & 0.69 & 0.67 & 0.96 \\
\hline Hydrolyzable N (\%) & 2.44 & 1.35 & 1.97 & 1.53 & 2.85 & 2.90 \\
\hline $\mathrm{NH}_{4}^{+}\left(\mathrm{mg} \mathrm{kg}^{-1}\right)$ & 5.70 & 2.50 & 3.50 & 0.10 & 2.50 & 0.40 \\
\hline $\mathrm{NO}_{3}^{-}\left(\mathrm{mg} \mathrm{kg}^{-1}\right)$ & nd & nd & nd & nd & nd & nd \\
\hline $\mathrm{P}_{2} \mathrm{O}_{5}(\%)$ & 16.0 & 9.89 & 13.3 & 9.09 & 7.46 & 13.2 \\
\hline $\mathrm{K}_{2} \mathrm{O}(\%)$ & 0.23 & 0.27 & 0.61 & 0.14 & 0.25 & 0.23 \\
\hline $\mathrm{Hg}\left(\mathrm{mg} \mathrm{kg}^{-1}\right)$ & 1.42 & 1.76 & 1.72 & 0.96 & 0.75 & 1.39 \\
\hline $\mathrm{Cd}\left(\mathrm{mg} \mathrm{kg}^{-1}\right)$ & $<0.5$ & $<0.5$ & $<0.5$ & $<0.5$ & $<0.5$ & $<0.5$ \\
\hline $\mathrm{Cr}\left(\mathrm{mg} \mathrm{kg}^{-1}\right)$ & 103.7 & 343.4 & 72.3 & 217.1 & 122.7 & 184.0 \\
\hline $\mathrm{Cu}\left(\mathrm{mg} \mathrm{kg}^{-1}\right)$ & 593 & 262 & 505 & 246 & 346 & 659 \\
\hline $\mathrm{Ni}\left(\mathrm{mg} \mathrm{kg}^{-1}\right)$ & 45.3 & 40.4 & 38.1 & 49.8 & 41.55 & 85.1 \\
\hline $\mathrm{Pb}\left(\mathrm{mg} \mathrm{kg}^{-1}\right)$ & 76.7 & 88.3 & 105 & 81 & 40.2 & 63.8 \\
\hline $\mathrm{Zn}\left(\mathrm{mg} \mathrm{kg}^{-1}\right)$ & 879 & 1,385 & 1,047 & 664 & 962 & 1346 \\
\hline LAS $\left(\mathrm{mg} \mathrm{kg}^{-1}\right)$ & 1,011 & 1,738 & 2,879 & 1,332 & 2,720 & 3,442 \\
\hline $\mathrm{NPE}\left(\mathrm{mg} \mathrm{kg}^{-1}\right)$ & 89 & 115 & 254 & 1,759 & 1,676 & 1,042 \\
\hline PCB $\left(\right.$ ng kg $\left.^{-1}\right)$ & 11.5 & 39.5 & 55.7 & 42.4 & 43.4 & 77.4 \\
\hline
\end{tabular}


1998) using a Microtox Model 500 Analyzer (Azur Environmental Inc.). This assay was based on the luminescence inhibition of cultures of the strain NRRL B-11177 of the marine bacteria $V$. fischeri. Sludge elutriates were prepared by the addition of dried and ground sludge samples (5 g) to $50 \mathrm{ml}$ of saline solution $(2 \% \mathrm{NaCl})$ in an Erlenmeyer flask. Then, the mixture was sonicated for $60 \mathrm{~min}$ at room temperature. After this period, the elutriates were vacuumfiltered in a $0.45-\mu \mathrm{m}$ pore size filter. Different dilutions of these final elutriates were then prepared to assess the effects on the luminescence of $V$. fischeri $\left(15 \mathrm{~min}\right.$ at $\left.15^{\circ} \mathrm{C}\right)$. Luminescence inhibition values $\left(\mathrm{EC}_{50}\right)$ were determined by means of the MicrotoxOmni Software (Azur Environmental Inc.).

The toxicity of the soil-sludge mixtures was determined in OECD artificial soil mixed with increasing concentrations of sludge. Artificial soil was prepared as indicated in the OECD Guideline 207 (OECD 207 1984). Toxicity was determined through the assessment of effects on germination and biomass production of three plant species, two dicots (Brassica rapa, Trifolium pratense), and a monocot (Lolium perenne), together with the survival and reproduction of the soil collembolan species $F$. candida.

Plant toxicity was assessed in accordance with OECD Guideline 208 (OECD 208 2006). A preliminary assay (0, $1,10,100,1,000 \mathrm{~g} \mathrm{~kg}^{-1}$ ) using germination as the endpoint was used to determine a range of concentrations showing an inhibition of $20-80 \%$ in order to define a definitive assay consisting of six concentrations in a geometric progression. Water content in soil-sludge mixtures was adjusted to $60 \%$ of maximum water-holding capacity. Each replicate consisted of a 250-ml plastic cup filled with $100 \mathrm{~g}$ of soil-waste mixture (dry weight) and incubated in a growth chamber at $21^{\circ} \mathrm{C}, 16: 8 \mathrm{~h}$ (light/dark), and $70 \%$ air humidity. Five replicates per concentration were prepared. Ten seeds per replicate were sown uniformly in each pot to a depth of approximately $2 \mathrm{~cm}$. When $50 \%$ of the seeds in the controls germinated, five seedlings were retained per replicate and the remaining plants were removed. At this moment, the germination percentage was determined. After 15 days, the aerial part of the seedlings was removed. The shoot length of each seedling was measured and the total biomass per replicate was weighed as dry weight $\left(24 \mathrm{~h}\right.$ at $\left.80^{\circ} \mathrm{C}\right)$.

Collembolan toxicity was assessed in accordance with ISO Guideline 11267 (ISO 1999). Ten concentrations were tested $(0,2,4.3,9.4,20.5,44.7,97.3,211.4,459.8$, and $100 \mathrm{~g}$ $\mathrm{kg}^{-1}$ ). Five replicates per concentration were prepared consisting of sealed $100-\mathrm{ml}$ plastic cups filled with $30 \mathrm{~g}$ of artificial soil-sludge mixture (dry weight) moistened to $60 \%$ of their maximum water-holding capacity. Ten individuals aged 10 to 12 days were added to each replicate and fed with $3 \mathrm{mg}$ of yeast at the start of the bioassay and after 14 days. After 28 days, the number of surviving adults and juveniles was determined. The procedure for this involved flooding the replicate content in a 500-ml Erlenmeyer flask followed by the addition of a dark dye to allow a picture of the individuals floating on the surface of the water surface to be taken. They were distinguishable by their light color. Adults and juveniles were differentiable by their size. The collembolan lethal concentration $\left(\mathrm{LC}_{50}\right)$ and effective concentrations for plant germination, shoot length, biomass, or collembolan reproduction $\left(\mathrm{EC}_{50}\right)$ together with their $95 \%$ confidence intervals were estimated using Statistica 6.0 (StatSoft Inc.) by suitable regression models (linear and non-linear), selected based on their best fit to the data.

\subsection{Field toxicity assessment: soil and leachate toxicity}

Within the limestone quarry area, extraction and trituration debris, hereafter referred to as soil, were mechanically mixed with fresh sludge (the same batches of fresh sludge used in the laboratory bioassays) and placed outdoors in lysimeters, exposed to the natural climatic conditions of the experimental site already described. The addition of sludge attempted to simulate that commonly used for restoration purposes and was calculated taking into account the composition of the mining debris and the sludges, with the aim of increasing organic matter content to $2 \%$. For the extraction debris, this was achieved by adding 107 and 171 tons $^{-1} \mathrm{ha}^{-1}$ (fresh weight) of thermally dried and composted sludges, respectively. For the trituration debris, it was necessary to add 62 and 99 tons ha $^{-1}$ (fresh weight) for thermally dried and composted sludges, respectively. Seven days after the beginning of the experiment, organic matter levels were between $1 \%$ and $2.9 \%$ in the amended lysimeters (Table 4), indicating the reasonable accuracy of the dosage calculation.

Four lysimeters were prepared for each soil-sludge combination together with four controls for each debris type. Each lysimeter consisted of a 150-1 polyethylene container $\left(0.33 \mathrm{~m}^{2}\right.$ surface area) filled with a 20 -cm layer of gravel and then a $30-\mathrm{cm}$ layer of amended soil substrate. At the bottom, each lysimeter had a lateral tap that allowed leachate collection in a 30-1 polyethylene bottle. At the beginning of the experiment, the lysimeters were sown with a mixture of seven grass species (Dactylis glomerata, Lolium multiflorum, Brachypodium retusum, Medicago sativa, Lotus corniculatus, Sanguisorba minor, Dorycnium pentaphyllum) at a density of $30 \mathrm{~g} \mathrm{~m}^{2}$. Lysimeters were irrigated initially with tap water and later with natural rain only. This mixture is commonly used in this region for mine reclamation and motorway slopes. Soil and leachate samples were collected from the lysimeters a week after the beginning of the experiment and a year afterwards. The leachates were obtained $24 \mathrm{~h}$ after the addition of $15 \mathrm{lof}$ mineral water to each lysimeter (corresponding to a $50-\mathrm{mm}$ rainfall event). Soil and leachate samples were preserved in a 


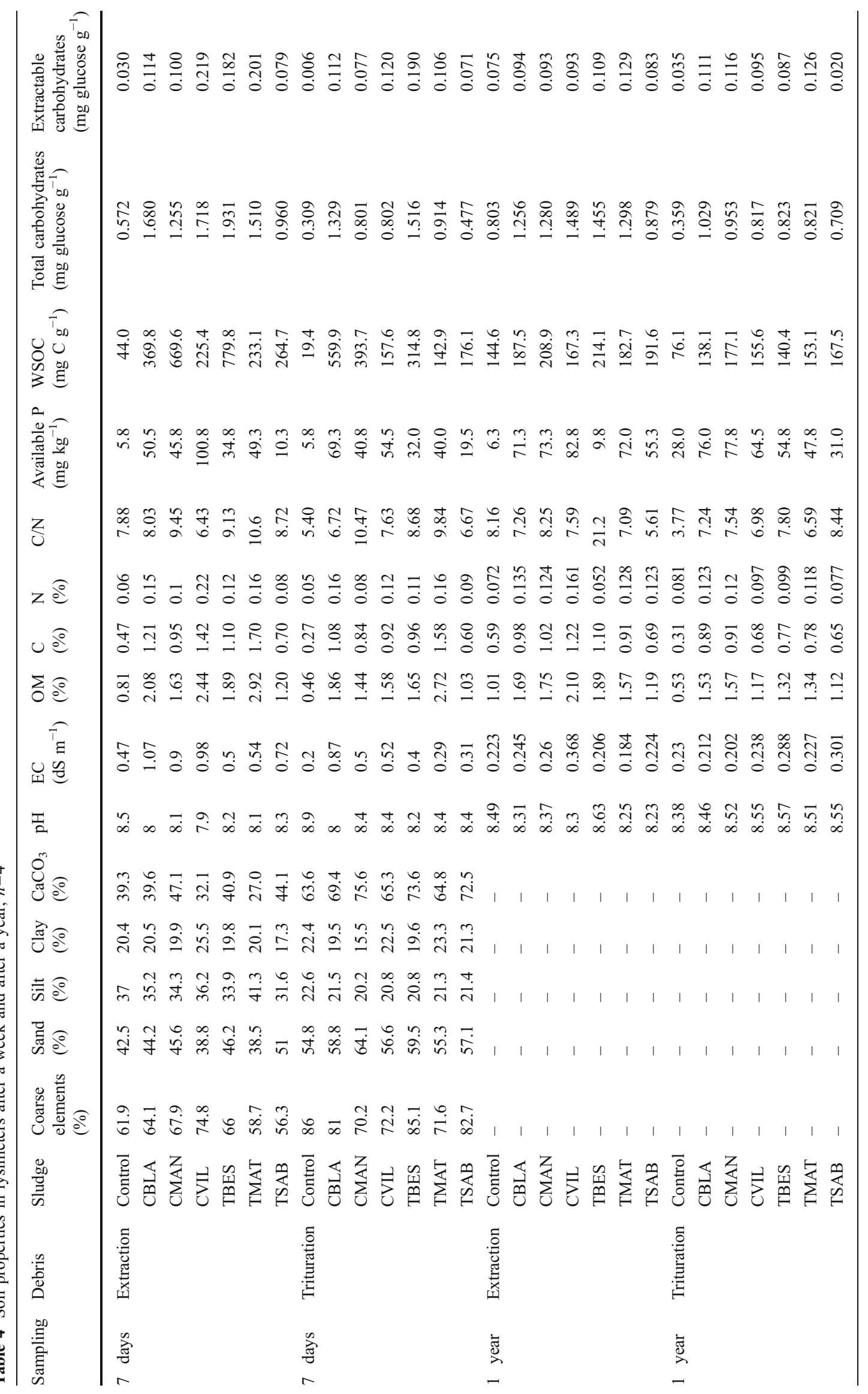


frozen state until the chemical and biological measures were performed. Any sample storage method produces changes in the microbial diversity and activities, but freezing is preferable to refrigeration for microbial studies (Stenberg et al. 1998). Frozen samples were used for the non-microbial bioassays and physicochemical analysis. Enzymatic activities were measured in soil collected before freezing and air-dried. Microbial biomass was measured from the same air-dried soil samples rewetted to $60 \%$ of the maximum water-holding capacity and incubated at $28^{\circ} \mathrm{C}$ for 7 days. Microbial respiration was measured from frozen samples rewetted to $50 \%$ of the maximum water-holding capacity and incubated at $21^{\circ} \mathrm{C}$ for 7 days (see methods below).

The soils were analyzed using the above-mentioned methods a week and a year after the beginning of the experiment. The usual soil properties were measured: granulometry (pipette method), calcium carbonate (Bernard calcimeter), total organic carbon (Walkley-Black titration method), total nitrogen (Kjeldahl method), and available phosphorus contents (Bray-Kurtz colorimetric method), together with $\mathrm{pH}$ and electrical conductivity (see Table 4). In addition, water-soluble organic carbon (WSOC; measured in a soil extract $(1: 4 \mathrm{~m} / \mathrm{v})$ with potassium sulfate $0.5 \mathrm{M}$ ), total carbohydrates (Cheshire and Mundie 1966), and extractable carbohydrates (soluble in $0.5 \mathrm{M} \mathrm{K}_{2} \mathrm{SO}_{4}$, according to Badalucco et al. 1992) were also measured.

The leachates were also analyzed a week and a year after the beginning of the experiment (Table 5). Heavy metal content in leachates $(\mathrm{Cd}, \mathrm{Cr}, \mathrm{Cr}, \mathrm{Hg}, \mathrm{Ni}, \mathrm{Pb}$, and $\mathrm{Zn})$ was determined after acidification with $1 \%$ of nitric acid, filtration, and direct measurement by atomic absorption spectrometry. Chlorates, nitrates, and sulfates were also measured by HPLC-IC after the filtration of a leachate sample in a $0.45-\mu \mathrm{m}$ nylon mesh. In addition, two organic pollutants (LAS and NPE) were also measured with the method described above for sludges after lyophilization of $100 \mathrm{ml}$ of leachate and resuspension in $10 \mathrm{ml}$ of methanol.

Different biological measurements were carried out in laboratory conditions with soil and leachate samples from
Table 5 Pollutant burden in leachates collected from the lysimeters a week and a year following the amendment
$\mathrm{Cd}, \mathrm{Cu}, \mathrm{Cr}, \mathrm{Hg}, \mathrm{Hg}, \mathrm{Ni}, \mathrm{Pb}, \mathrm{Zn}$, LAS, and NPE were below their detection limit $\left(<0.1 \mathrm{mg}^{-1}\right)$; $n=4$

\begin{tabular}{|c|c|c|c|c|c|}
\hline Sampling & Debris & Sludge & Chlorides $\left(\mathrm{mg} \mathrm{l}^{-1}\right)$ & Nitrates $\left(\mathrm{mg}^{-1}\right)$ & Sulfates $\left(\mathrm{mg} \mathrm{l}^{-1}\right)$ \\
\hline \multirow[t]{7}{*}{7 days } & \multirow[t]{7}{*}{ Extraction } & Control & 62 & 241 & 517 \\
\hline & & CBLA & 149 & 201 & 639 \\
\hline & & CMAN & 41 & 39 & 148 \\
\hline & & CVIL & 326 & 1,712 & 816 \\
\hline & & TBES & 370 & 2,932 & 551 \\
\hline & & TMAT & 124 & 1,518 & 381 \\
\hline & & TSAB & 144 & 2,003 & 471 \\
\hline \multirow[t]{7}{*}{7 days } & \multirow[t]{7}{*}{ Trituration } & Control & 67 & 158 & 175 \\
\hline & & CBLA & 134 & - & 246 \\
\hline & & CMAN & 186 & 1,285 & 419 \\
\hline & & CVIL & 123 & 233 & 238 \\
\hline & & TBES & 142 & 2,834 & 471 \\
\hline & & TMAT & 344 & 2,726 & 554 \\
\hline & & TSAB & 191 & 1,992 & 381 \\
\hline \multirow[t]{7}{*}{1 year } & \multirow[t]{7}{*}{ Extraction } & Control & 42 & 15 & 68 \\
\hline & & CBLA & 56 & 20 & 81 \\
\hline & & CMAN & 46 & 48 & 70 \\
\hline & & CVIL & 51 & 21 & 78 \\
\hline & & TBES & 53 & 22 & 109 \\
\hline & & TMAT & 44 & 16 & 54 \\
\hline & & TSAB & 45 & 20 & 118 \\
\hline \multirow[t]{7}{*}{1 year } & \multirow[t]{7}{*}{ Trituration } & Control & 65 & 14 & 64 \\
\hline & & CBLA & 45 & 15 & 50 \\
\hline & & CMAN & 35 & 11 & 38 \\
\hline & & CVIL & 49 & 17 & 51 \\
\hline & & TBES & 45 & 15 & 53 \\
\hline & & TMAT & 46 & 15 & 62 \\
\hline & & TSAB & 47 & 17 & 56 \\
\hline
\end{tabular}


lysimeters to assess the environmental impact for soils and groundwater of the amendments with sludges. The measurements were carried out a week and a year after the beginning of the experiment. More precisely, several microbiological endpoints were measured: basal respiration (according to Hernández and García 2003), total microbial biomass (fumigation-extraction method, according to Vance et al. 1987), microbial respiration (according to Anderson 1982), the metabolic quotient (respiration per biomass unit), and enzymatic activities ( $\beta$-glucosidase and $\beta$-galactosidase, according to Eivazi and Tabatabai 1988). The effects on collembolan survival and reproduction were also assessed using the protocol mentioned above (ISO 1999).

Furthermore, an assessment was also made of the potential impact of the leachates obtained on the two sampling times by means of a Microtox bioassay, as described in a previous section.

\section{Results}

\subsection{Laboratory toxicity assessment}

\subsubsection{Sludge composition}

As shown in Table 3, all the sludges displayed a $\mathrm{pH}$ of around 7 and similar organic matter and total nitrogen contents $(55 \%$ to $74 \%$ and $2 \%$ to $4 \%$, respectively), but differed markedly in their electrical conductivities. They showed similar levels of stable organic matter, around $36 \%$ and $41 \%$. Low stability was found in CBLA (29\%), suggesting a poor composting efficiency. Moreover, similar values were found for hydrolyzable and non-hydrolyzable nitrogen. The higher ammonium levels were found in CBLA and CVIL, while nitrate was not detected in any of the sludges.

Concerning pollutant concentrations, all the sludges could be applied to soils according to current European legislation (Directive 86/278/EEC), since all the metals were below the limit values of this Directive, and even below the proposal of the new draft Directive (European Commission 2000). However, organic pollutant levels were high in relation to the limit values defined in the abovementioned draft. More precisely, LAS was clearly over the limit value $\left(2,600 \mathrm{mg} \mathrm{kg}^{-1}\right)$ in TSAB, and slightly above in CVIL and TMAT. Furthermore, NPE was over the suggested maximum concentrations of the draft $\left(50 \mathrm{mg} \mathrm{kg}^{-1}\right)$ in all of the sludges studied, several times in most of the sludges.

\subsubsection{Sludge toxicity comparison}

Concerning the direct toxicity results determined in laboratory conditions (Table 6 and Fig. 1), these displayed clearly different toxicities with increasing concentrations

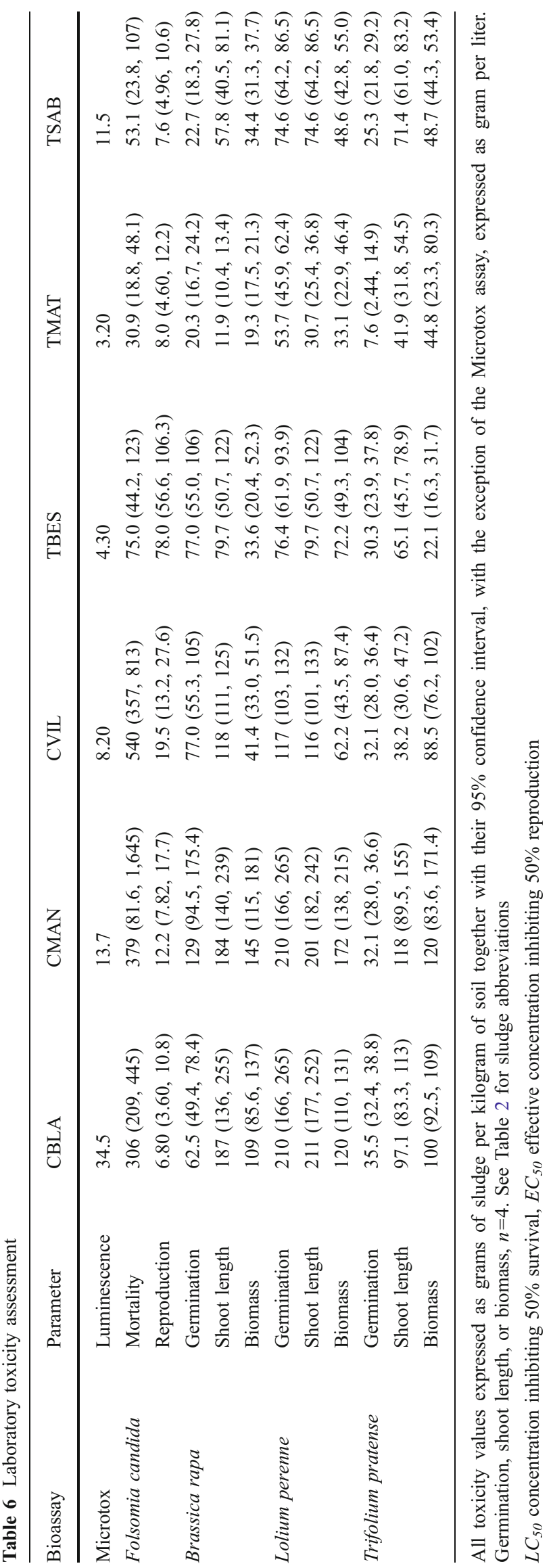


Fig. 1 Toxicity values obtained in the different bioassays for each sludge. $I C_{50}$ concentration of sludge inhibiting $50 \%$ the biological endpoint expressed as gram per kilogram in all the bioassays with the exception of the Microtox assay which was expressed as gram per liter

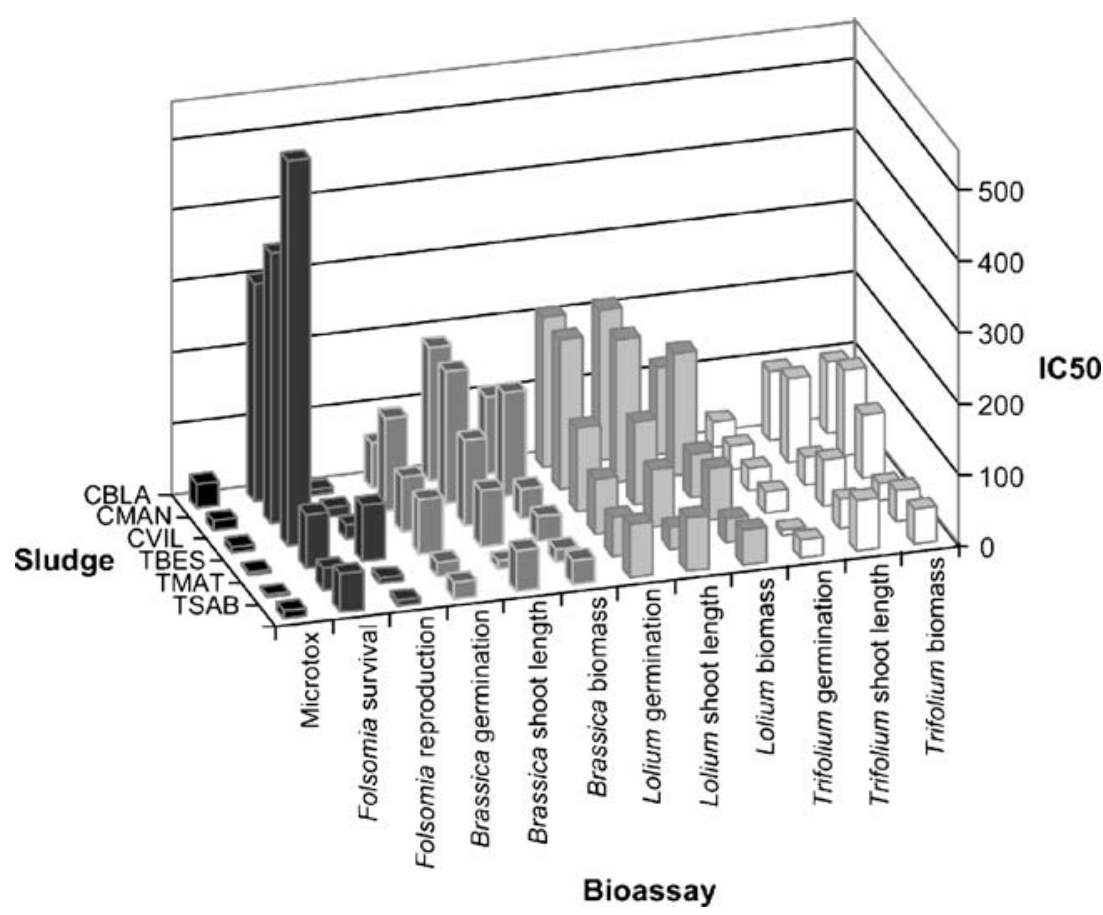

for each sludge type. In general, composted sludges displayed lower toxicities than thermally dried sludges both in elutriate and soil assays. More precisely, TMAT was the most toxic sludge in all the bioassays and endpoints assessed, followed by TSAB, while TBES showed intermediate toxicities. It is also worth pointing out the intermediate toxicity of CVIL for collembolan reproduction and most plant endpoints. Concerning the sensitivity of test organisms to sludge, collembolan reproduction and plant germination were the most sensitive endpoints, while collembolan survival was the least sensitive. On the other hand, $L$. perenne appeared to be the more resistant plant species to sludge compared to T. repens, which displayed the highest sensitivity.

No negative correlations between toxicity results and physicochemical properties and pollutant burden were found in leachates using the Microtox assay. On the contrary, a negative correlation was found between collembolan survival and total NPE content (Pearson correlation, $r=-0.851, p=$ 0.032 ) and between the number of juveniles and stable organic matter $(r=-0.917, p=0.01)$. Concerning plant germination assays, we found a negative correlation with total nitrogen content (B. rapa $r=-0.873, p=0.023$ ), nonhydrolyzable nitrogen (B. rapa $r=-0.93, p=0.007$ ), total NPE content (L. perenne $r=-0.867, p=0.25$ ), and with NPEO1 content (T. repens $r=-0.949, p=0.004)$. When shoot length was used as endpoint, negative correlations were found with NPEO1 in B. rapa $(r=-0.816, p=0.048)$ and total NPE in B. rapa $(r=-0.87, p=0.024)$ and $L$. perenne $(r=-0.869, p=0.025)$. Concerning the effects on plant biomass, negative correlations were found with total NPE content in T. repens ( $r=-948, p=0.004)$.

When the outcomes of the different bioassays were compared, the Microtox assay and the collembolan toxicity results failed to correlate with plant assays. On the other hand, most plant endpoints displayed similar outcomes for the different plant species. The most intercorrelated endpoint was biomass, followed by shoot length and germination rate $(p<0.05)$. L. perenne biomass had the highest correlations with the remaining endpoints and species.

\subsection{Field toxicity assessment}

\subsubsection{Short- and long-term effects on physicochemical properties}

Soil physicochemical properties varied in sludge-amended lysimeters compared to controls, as shown in Table 4. The addition of composted and thermally dried sludge increased total organic carbon and water-soluble carbon, total and extractable carbohydrates, and total nitrogen contents (oneway ANOVA, $p<0.05)$. These increased values persisted after a year $(p<0.05)$, with the exception of extractable carbohydrates in extraction debris and $\mathrm{C} / \mathrm{N}$ ratio in both debris, which were not significantly different to those found in the controls. No differences between the addition of composted or thermally dried sludges were detected (minimum significant difference post hoc test (MSD), $p<$ 0.05 ) for any physicochemical property, neither in the first 
sampling nor in the last sampling (with the exception of extraction debris after a year, which displayed higher values of carbon and nitrogen in compost-amended lysimeters).

In addition, a significant decrease in $\mathrm{pH}$ was observed with sludge addition after a week (one-way ANOVA, $p<$ $0.05)$. This was significantly higher in composted sludgeamended lysimeters (MSD, $p<0.05)$. After a year, the $\mathrm{pH}$ values were not significantly different in extraction debris, but these lower values persisted in trituration debris. On the other hand, electrical conductivity increased with sludge addition, remaining a year after (one-way ANOVA, $p<$ 0.05 ), and at a higher level, when the lysimeters were amended with composted sludges (MSD, $p<0.05$ ).

Physicochemical properties and heavy metal and organic pollutant burden in leachates obtained from the lysimeters are shown in Table 5. In general terms, pollutant content was low, since neither heavy metals nor organic pollutants were detectable. Only the levels of $\mathrm{Zn}$ were detectable a week and a year following the amendment, together with $\mathrm{Ni}$, which was only detectable after a year. Anion concentrations (chlorides, nitrates, and sulfates) were significantly higher in lysimeters amended with sludges (ANOVA, $p<0.05$ ) and were higher in those amended with thermally dried sludges (MSD, $p<0.05$ ). However, these concentrations decreased after a year by several orders of magnitude in amended lysimeters to non-significant levels compared to the controls.

\subsubsection{Short- and long-term effects on microbial endpoints}

Field effects of the amendments with sludges are shown in Table 7. Generally, different effects were observed a week and a year after the amendment in most of the biological endpoints assessed.

Concerning microbial endpoints, a clear stimulation in biomass and respiration both in extraction and trituration debris was observed a week after the amendment compared to the controls (one-way ANOVA, $p<0.05$ ). This stimulation was higher for thermally dried sludges than for sludge composts (MSD, $p<0.05)$. After a year, the stimulation in microbial biomass and respiration disappeared with the exception of microbial biomass in trituration debris, which displayed higher levels in lysimeters amended with composted sludge, and even higher ones in those that had been amended with thermally dried sludges.

A week after the amendment, the metabolic quotient showed lower values in controls than in sludge-amended lysimeters with extraction debris (ANOVA, $p<0.05$ ), but no significant values in trituration debris. Identical values were observed after a year in both debris lysimeters.

Concerning enzymatic activities (glucosidase and galactosidase), global significant differences were not observed in amended lysimeters compared to controls a week after the amendment. However, in extraction debris, significantly higher enzymatic activity values were found, both for galactosidase and glucosidase, in lysimeters amended with thermally dried sludge compared to controls (DMS, $p=$ 0.041 and $p=0.025$, respectively). On the other hand, a year later, significantly higher enzymatic activities were observed in sludge-amended lysimeters compared to control (ANOVA, $p<0.05$ ), with the exception of galactosidase activity in extraction debris. In extraction debris, this higher enzymatic activity was exclusively observed in lysimeters amended with thermally dried sludge (MSD, $p=0.009$ ). However, in trituration debris, both composted and thermally dried sludge induced higher enzymatic activity values (MSD, $p<0.002$ ), but higher glucosidase activities were observed in lysimeters amended with thermally dried sludge compared to composted sludge (MSD, $p=0.030$ ).

\subsubsection{Short- and long-term effects on soil fauna}

No significant differences in survival or reproduction (number of juveniles) were observed between amended lysimeters and controls, neither at the beginning nor after a year (ANOVA, $p<0.05$ ). The only exception was extraction debris a week after the amendment, where both survival and reproduction were significantly inhibited (ANOVA, $p<$ 0.05 ), and more precisely by composted sludges (MSD, $p<$ 0.05 ). However, any inhibitory effect to soil collembolans disappeared after a year.

Concerning the leachates obtained from lysimeters a week and a year later, no inhibitory effects compared to controls were detectable from the Microtox assay when direct tests with undiluted leachates were carried out.

\subsubsection{Correlation between physicochemical and biological properties}

Taking into account the data as a whole (combining debris type, sludge, and sampling), microbial biomass and soil respiration were positively influenced by total and extractable carbohydrates, water-soluble carbon, total carbon and nitrogen contents, and $\mathrm{C} / \mathrm{N}$ ratio (Pearson, $p<0.004$ ). Microbial biomass and soil respiration were negatively influenced by $\mathrm{pH}(r=-0.336, p=0.0011)$. On the other hand, no correlations were found for the metabolic quotient.

These correlations were generally maintained at the first sampling in both extraction and trituration debris. The exception in the latter debris was soil respiration, which did not correlate with total and extractable carbohydrates. After a year, these correlations were also maintained in extraction debris with the exception of total nitrogen content and $\mathrm{pH}$, which failed to correlate with microbial biomass and soil respiration in this sampling. On the other hand, most of the correlations disappeared in trituration debris, with the 
Table 7 Field toxicity assessment

\begin{tabular}{|c|c|c|c|c|c|c|c|c|c|}
\hline Sampling & Debris & Sludge & $\begin{array}{l}\text { Soil } \\
\text { respiration } \\
\left(\mathrm{mg} \mathrm{CO}_{2} / \mathrm{kg} \mathrm{h}\right)\end{array}$ & $\begin{array}{l}\text { Microbial } \\
\text { biomass } \\
\left(\mu \mathrm{g} \mathrm{C}^{-1}\right)\end{array}$ & $\begin{array}{l}\text { Metabolic } \\
\text { quotient }\end{array}$ & $\begin{array}{l}\text { Glucosidase } \\
\text { activity }(\mu \mathrm{mol} \\
p \text {-nitrophenol } \\
\left.\mathrm{g}^{-1} \mathrm{~h}^{-1}\right)\end{array}$ & $\begin{array}{l}\text { Galactosidase } \\
\text { activity }(\mu \mathrm{mol} \\
p \text {-nitrophenol } \\
\left.\mathrm{g}^{-1} \mathrm{~h}^{-1}\right)\end{array}$ & $\begin{array}{l}\text { Adult } \\
\text { collembolans } \\
\text { (no.) }\end{array}$ & $\begin{array}{l}\text { Juvenile } \\
\text { collembolans } \\
\text { (no.) }\end{array}$ \\
\hline \multirow[t]{7}{*}{7 days } & \multirow[t]{7}{*}{ Extraction } & Control & 1.67 & 37.4 & 0.046 & 0.086 & 0.005 & 9.6 & $1,040.4$ \\
\hline & & CBLA & 2.69 & 209.0 & 0.015 & 0.249 & 0.046 & 8.8 & 664.5 \\
\hline & & CMAN & 3.83 & 138.6 & 0.030 & 0.206 & 0.026 & 8.5 & 803.3 \\
\hline & & CVIL & 5.19 & 253.0 & 0.022 & 0.497 & 0.062 & 8.6 & 239.4 \\
\hline & & TBES & 8.15 & 492.1 & 0.018 & 0.679 & 0.118 & 9.4 & 641.0 \\
\hline & & TMAT & 24.19 & 641.0 & 0.039 & 0.341 & 0.057 & 8.8 & 185.0 \\
\hline & & TSAB & 1.69 & 80.8 & 0.021 & 0.276 & 0.016 & 9.3 & 950.5 \\
\hline \multirow[t]{7}{*}{7 days } & \multirow[t]{7}{*}{ Trituration } & Control & 1.48 & 31.8 & 0.030 & 0.007 & 0.000 & 9.0 & $1,157.1$ \\
\hline & & CBLA & 6.42 & 170.9 & 0.062 & 0.239 & 0.043 & 9.4 & 694.4 \\
\hline & & CMAN & 2.51 & 124.0 & 0.020 & 0.127 & 0.014 & 8.4 & 952.2 \\
\hline & & CVIL & 3.42 & 127.7 & 0.027 & 0.165 & 0.022 & 9.1 & 412.9 \\
\hline & & TBES & 10.04 & 574.3 & 0.019 & 1.158 & 0.103 & 9.1 & $1,013.8$ \\
\hline & & TMAT & 21.08 & 554.7 & 0.038 & 0.038 & 0.005 & 9.6 & 403.0 \\
\hline & & TSAB & 6.79 & 221.2 & 0.047 & 0.125 & 0.020 & 9.0 & 970.1 \\
\hline \multirow[t]{7}{*}{1 year } & \multirow[t]{7}{*}{ Extraction } & Control & 1.38 & 213.0 & 0.006 & 0.277 & 0.048 & 8.6 & 696.4 \\
\hline & & CBLA & 1.64 & 231.7 & 0.007 & 0.417 & 0.060 & 7.6 & 791.1 \\
\hline & & CMAN & 1.89 & 219.4 & 0.009 & 0.650 & 0.087 & 6.9 & 928.4 \\
\hline & & CVIL & 2.95 & 296.8 & 0.011 & 0.610 & 0.080 & 7.5 & 911.1 \\
\hline & & TBES & 2.40 & 243.4 & 0.010 & 1.075 & 0.124 & 6.9 & 845.9 \\
\hline & & TMAT & 1.52 & 259.9 & 0.006 & 0.489 & 0.073 & 7.4 & 913.4 \\
\hline & & TSAB & 1.05 & 189.6 & 0.006 & 0.477 & 0.062 & 6.5 & 739.9 \\
\hline \multirow[t]{7}{*}{1 year } & \multirow[t]{7}{*}{ Trituration } & Control & 0.87 & 95.5 & 0.011 & 0.094 & 0.025 & 8.6 & 865.6 \\
\hline & & CBLA & 2.83 & 228.8 & 0.013 & 0.481 & 0.101 & 8.3 & $1,201.6$ \\
\hline & & CMAN & 3.07 & 136.1 & 7.612 & 0.514 & 0.102 & 7.3 & 878.4 \\
\hline & & CVIL & 1.94 & 205.0 & 0.010 & 0.560 & 0.067 & 3.5 & 539.1 \\
\hline & & TBES & 6.36 & 259.2 & 0.026 & 1.017 & 0.073 & 4.4 & 601.8 \\
\hline & & TMAT & 2.09 & 312.5 & 0.007 & 0.647 & 0.095 & 9.0 & $1,186.3$ \\
\hline & & TSAB & 2.53 & 207.5 & 0.012 & 0.496 & 0.099 & 3.0 & 284.8 \\
\hline
\end{tabular}

Biological measurements in soil and leachate samples from lysimeters a week and a year after the application of the sludges. No inhibition was detected in the Microtox assay, $n=4$

exception of the positive correlation with water-soluble carbon $(r=0.589, p=0.001)$ and carbon content $(r=0.486$, $p=009)$. It is also worth noting that for extraction debris, the metabolic quotient was shown to correlate positively with carbon content at the last sampling $(p<0.05)$, a fact not observed in the first sampling.

Concerning the enzymatic activities measured, and taking all the data together as a whole, glucosidase and galactosidase activities correlated positively with total and extractable carbohydrates, water-soluble carbon, and total carbon and nitrogen contents $(p<0.05)$. These positive correlations were again observed in the first sampling but, in addition, some negative correlations were also observed. More precisely, both in extraction and trituration debris, a decrease in enzymatic activities values was observed with increasing $\mathrm{pH}(p<0.04)$. A year later, all these correlations were maintained with the exception of the negative correlations with $\mathrm{pH}$.

Analyzing all the data as a whole, the number of surviving collembolans correlated negatively with $\mathrm{pH}(p<0.03)$. However, when this trend was analyzed for the different debris and sampling times, it was only observed for $\mathrm{pH}$ in the trituration debris in the last sampling $(p=0.006)$.

Concerning the number of collembolan offspring produced, a negative correlation was found with total and extractable carbohydrates $(r=-0.236, p=0.012$ and $r=$ $-0.373, p<0.001$, respectively), water-soluble carbon $(r=$ $-0.514, p<0.001)$, electrical conductivity $(r=-0.282, p=$ $0.003)$, total carbon and nitrogen content $(r=-0.455, p<$ 0.001 and $r=-0.371, p<0.001$, respectively), and $\mathrm{C} / \mathrm{N}$ ratio 
$(r=-0.191, p=0.044)$. A positive correlation for the number of juveniles was found with $\mathrm{pH}(r=0.306, p=0.001)$. These correlations were generally the same in the first sampling for both debris types, with the exception of the $\mathrm{C} / \mathrm{N}$ ratio. After a year, no correlations had disappeared.

Most of the biological parameters measured displayed equivalent responses. More precisely, positive correlations were found between microbial biomass and soil respiration $(r=0.718, p<0.001)$, with glucosidase activity $(r=0.422$, $p<0.001)$ and galactosidase activity $(r=0.419, p<0.001)$. On the other hand, negative correlations were found between microbial biomass and the number of collembolan juveniles $(r=-0.295, p=0.02)$, but also between soil respiration and the number of juveniles $(r=-0.424, p<0.002)$.

Concerning enzymatic activities, and in addition to the positive correlation with microbial biomass mentioned above, a negative correlation was observed with collembolan survival $(p<0.009)$.

\section{Discussion}

\subsection{Use of mining debris as reclamation substrate}

Mining debris is generally characterized by its poor ability to support a functional terrestrial ecosystem. In addition to its low organic matter and nutrient content (see Table 1), the debris displayed poor physical properties as reflected by its extreme texture (mainly coarse elements with fine fraction dominated by silt and clay). Moreover, it also showed poor chemical properties, as shown by the high $\mathrm{pH}$ and the low organic matter and nutrient contents, together with its low biological activity.

A week after the amendment, there was clearly a lower biological activity in the controls (as shown by the lower microbial biomass and respiration). After a year, this reduced activity was more easily observable, and despite the development of some degree of vegetation cover, lower enzymatic activities were found in comparison to the lysimeters amended with sludge. This inferior performance is coupled with reduced contents of total and water-soluble carbon levels, carbohydrates, and total nitrogen compared to amended debris.

On the other hand, the performance of collembolans in control lysimeters was generally similar to that of amended ones, and slight inhibitory effects were only observed in the extraction debris in the first sampling. The unexpected lack of differences in collembolan performance may be explained by the addition of yeast as a food source to carry out the bioassay (which lasted a month) and would probably not have been observed in the first sampling in these substrates with such a low organic matter content.
Consequently, when used in isolation, the mining debris used in our study showed a poor capacity for biological recovery, as shown by its inferior ability to sustain biological communities compared to lysimeters amended with sludge.

\subsection{Effects of amendment with sludge}

The addition of sludge clearly improved the debris in terms of its physicochemical and biological properties. However, no clearly different effects of the post-treatments (composting and thermally drying) could be found for physicochemical properties. This is in accordance with the low variability of composition of our sludges (only important for organic matter stability and related parameters) and the low proportion of sludge in lysimeters, but is at odds with the usually huge variability in the composition of sludges in terms of physicochemical properties and pollutant content (European Commission 2001).

On the other hand, some significant differences could be observed for some biological properties, agreeing with the variation of results observed in the ecotoxicological assays carried out in laboratory conditions in this study.

More precisely, an initially higher stimulation of microbial biomass and respiration was observed when thermally dried sludges were used compared to composted sludges. This agrees with other studies and has been related to the generally higher content in labile organic matter (Fernández et al. 2007) and their fine particle size, which facilitates the attack of microorganisms. After a year, this higher ability of thermally dried sludges to stimulate soil microorganisms disappears in extraction debris, but is maintained in amended trituration debris, which shows higher microbial biomass levels. Similarly, thermally dried sludges allowed higher enzymatic activity values (glucosidase and galactosidase) a year after the amendment, a trend not observed in the first sampling. Thermally dried sludges also showed lower toxicity for collembolan performance in the first sampling. These results, obtained in lysimeters, seem to contradict those obtained in the laboratory assays, which predicted higher toxicity of thermally dried sludges. However, this may not be a contradiction, but complementary information, since the comparison of toxicities obtained in the laboratory was carried out taking into account the concentration inhibiting $50 \%$ of the biological endpoint assessed, a severe inhibition not observed in lysimeter conditions.

No toxicity could be observed in the leachates obtained from the lysimeters using the Microtox assay, indicating a low migration of noxious pollutants along the lysimeter soil column.

The effects on biological endpoints were mainly mediated by similar physicochemical properties, but in the opposite sense depending on the organism. Microbial 
biomass and respiration and glucosidase and galactosidase activities correlate positively with parameters reflecting a low stability of organic matter (elevated carbon, nitrogen, and carbohydrate contents, high $\mathrm{C} / \mathrm{N}$ ratio), while $\mathrm{pH}$ correlated negatively with microbial endpoints. This last trend was also observed for collembolan survival, but in this case it may only reflect the decrease in $\mathrm{pH}$ associated with the addition of sludge. The higher microbial performance in lysimeters with high contents in labile organic matter (more easily mineralizable) makes much sense, since more labile organic matter is available for microorganisms (mainly polysaccharides and proteins) (Rovira and Vallejo 2002). In addition, no significant effects on the metabolic quotient were found. This is considered to be a marker of the environmental disturbance or stress of the microbial population (Anderson and Domsch 1993).

On the other hand, collembolans showed the opposite pattern to that observed in microbial endpoints, since collembolan reproduction was negatively associated to a low stability of the organic matter present in lysimeters (higher levels of carbohydrates, organic matter, $\mathrm{C} / \mathrm{N}$ ratio), agreeing with the results in laboratory tests, and was also associated with higher electrical conductivity. This correlation was also significant in the last sampling, indicating the sensitivity of collembolan reproduction to sludge addition. This result agrees with other studies that have suggested an enhanced toxicity of organic wastes with low organic matter stability for soil fauna (Domene et al. 2008) and plants (Zucconi et al. 1981; Pascual et al. 1997; Zmora-Nahum et al. 2005), a trend that has been more specifically linked to ammonium and other nitrogen forms (Katayama et al. 1985; Seniczak et al. 1994; Neher 1999). The significant negative correlations of biological endpoints (collembolan survival and plant endpoints) with NPE levels, rather than being a true trend are probably an artefact for two main reasons. First, their levels are not expected to be noxious for collembolans (Scott-Fordsmand and Krogh 2004). Second, lower NPE concentrations are associated with sludges with higher organic matter stability (composted sludges), since composting processes allow quick microbial degradation of NPE (Moeller and Reeh 2003), which are also the less toxic in this study because of their higher stability.

\section{Conclusions}

The physicochemical properties of mining debris used for reclamation are clearly improved by the addition of sewage sludge (composted or thermally dried). Equally, biological properties are also positively influenced by sludge addition, as shown by the increased performance of microorganisms, and indicate an enhanced capacity of mining debris as a biological habitat. The degree of microbial stimulation is linked to a higher content of labile organic matter (easily mineralizable), which is quickly used as growing media by soil microorganisms.

On the other hand, inhibitory effects were detected for collembolan performance, but only in the first sampling, since after a year no impairment in their reproduction was observed. The inhibitory effects observed in collembolan reproduction are significantly linked to parameters reflecting a higher content in labile organic matter.

However, the environmental risk found in the first sampling should not be a limitation for the use of sludge in mine reclamation, since no impacts may occur on soil fauna populations just before the amendment is carried out because no individuals are initially present in mining debris. Later, the progressive disappearance of any noxious effect of sludge on soil fauna is expected to be coupled with a progressive colonization by individuals from surrounding natural environments.

In addition, no noxious effects were observed in leachates resulting from amended debris, even a week after the application of sludge.

\section{Recommendations and perspectives}

The results from this study indicate that the use of mining debris mixed with sewage sludges at the amendment rates used in this study may be a suitable substrate for mining reclamation in terms of biological habitat, since long-term ecotoxicological risks were not observed. In addition, the results support and recommend the use of bioassays for the prediction of the success or risk of specific land reclamation practices in order to avoid unsuccessful attempts.

Acknowledgments This study has been funded by the RESMINLOD project, co-funded by the Spanish Ministry of Environment (MMA) and the Water Agency of the Catalonia Government (ACA). We also thank the Institut Químic de Sarria (IQS) for carrying out the analysis of organic pollutants and the Microtox assay.

\section{References}

Al-Assiuty AIM, Khalil MA, Abdel-Lateif HM (2000) Effects of dry sludge application on soil microarthropod communities in a reclaimed desert ecosystem. Pedobiologia 44:567-578

Alvarenga P, Palma P, Gonçalves AP, Baião N, Fernandes RM, de Varennes A, Vallini G, Duarte E, Cunha-Queda AC (2008) Assessment of chemical, biochemical and ecotoxicological aspects in a mine soil amended with sludge of either urban or industrial origin. Chemosphere 72:1774-1781

Anderson JPE (1982) Soil Respiration. In: Page AL, Miller RH, Keeney DR (eds) Methods of soil analysis. Part 2. Chemical and microbiological properties. American Society of Agronomy, Madison, USA, pp 831-871 
Anderson TH, Domsch KH (1993) The metabolic quotient for CO2 (qCO2) as a specific activity parameter to assess the effects of environmental conditions, such as $\mathrm{pH}$, on the microbial biomass of forest soils. Soil Biol Biochem 25:393-395

Andrés P (1999) Ecological risks of the use of sewage sludge as fertilizer in soil restoration: effects on the soil microarthopod populations. Land Degrad Dev 10:67-77

Andrés P, Domene X (2005) Ecotoxicological and fertilizing effects of dewatered, composted and dry sewage sludge on soil mesofauna: a TME experiment. Ecotoxicology 14:545-557

Badalucco L, Gelsomino A, Dell'Orco S, Grego S, Nannipieri P (1992) Biochemical characterization of soil organic compounds extracted by $0.5 \mathrm{M} \mathrm{K}_{2} \mathrm{SO}_{4}$ before and after chloroform fumigation. Soil Biol Biochem 24:569-578

Barrera I, Andrés P, Alcañiz JM (2001) Sewage sludge application on soil: effects on two earthworm species. Water Air Soil Pollut 129:319-332

Brown SL, Henry CL, Chaney R, Compton H, DeVolver PS (2003) Using municipal biosolids in combination with other residuals to restore metal-contaminated mining areas. Plant Soil 249: 203-215

Cheshire MV, Mundie CM (1966) The hydrolyic extraction of carbohydrates from soil by sulfuric acid. Eur J Soil Sci 24:54-68

Domene X, Ramírez W, Mattana S, Alcañiz JM, Andrés P (2008) Ecological risk assessment of organic waste amendments using the species sensitivity distribution from a soil organisms test battery. Environ Pollut 155:227-236

Eivazi F, Tabatabai MA (1988) Glucosidases and galactosidases in soils. Soil Biol Biochem 20:601-606

EN 13037 (1999) Soil improvers and growing media - determination of pH. European Committee for Standardization, Brussels, pp 1-12

EN 13038 (1999) Soil improvers and growing media-determination of electrical conductivity. European Committee for Standardization, Brussels, pp 1-12

EN 12879 (2000) Characterization of sludges - determination of the loss of ignition of dry mass. European Committee for Standardization, Brussels, pp 1-14

EN 12880 (2000) Characterization of sludges - determination of dry residue and water content. European Committee for Standardization, Brussels, pp 1-17

EN 13342 (2000) Characterization of sludges - determination of Kjeldahl nitrogen. European Committee for Standardization, Brussels, pp 1-16

European Commission (2000) Working Document on Sludge. 3rd Draft. European Commission, DG Environment, Waste Management Unit. ENV.E3/LM, Brussels, Belgium, pp 1-19

European Commission (2001) Pollutants in Urban waste water and sewage sludge. Final Report to DG Environment, European Commission. IC Consultants Ltd, London, UK, http://ec.europa. eu/environment/waste/sludge/pdf/sludge_pollutants.pdf

Fernández JM, Plaza C, Hernández D, Polo A (2007) Carbon mineralization in an arid soil amended with thermally-dried and composted sewage sludges. Geoderma 137:497-503

Hernández T, García C (2003) Estimación de la respiración microbiana del suelo. (Estimation of microbial soil respiration). In: García C, Hernández T, Gil-Sotres F, Trasar-Cepeda C (eds) Técnicas de análisis de parámetros bioquímicos en suelo. Medidas de actividades enzimáticas y biomasa microbiana. (Techniques for the analysis of biochemical parameters in soil. Measurements of enzymatic activities and microbial biomass). Mundi Prensa, Madrid, Spain, pp 313-346

ISO 11885 (1996) Water quality - determination of 33 elements by inductively coupled plasma atomic emission spectroscopy. International Organization for Standardization, Geneva, Switzerland, pp 1-22
ISO 11267 (1999) Soil quality-inhibition of reproduction of collembola (Folsomia candida) by soil pollutants. International Organization for Standardization, Geneva, Switzerland, pp 1-16

ISO 11348-3 (1998) Water quality - determination of the inhibitory effect of water samples on the light emission of Vibrio fischeri (luminescent bacteria test) - part 3: method using freeze-dried bacteria. International Organization for Standardization, Geneva, Switzerland, pp 1-24

Jiménez P, Ortiz O, Tarrasón D, Guinovart M, Bonmatí M (2007) Effect of differently post-treated dewatered sewage sludge on $\beta$ glucosidase activity, microbial biomass carbon, basal respiration and carbohydrates contents of soils from limestone quarries. Biol Fert Soils 44:393-398

Katayama A, Hirai M, Shoda M, Kubota H (1985) Inhibitory factor of sewage sludge compost for growth of Komatsuna Brassica campestris L. var. rapifera. Environ Pollut (Series A) $38: 45-62$

Ministère de l'Agriculture de Belgique (1971) Méthodes de convention pour l'analyse des engrais et des amendements du sol. Div. B. Ad. Services Economiques d'Inspection de Matières Premièries. Partie II, Brussels, Belgium, pp 202-203

Moeller J, Reeh U (2003) Degradation of nonylphenol ethoxylates (NPE) in sewage sludge and source separated municipal solid waste under bench-scale composting conditions. Bull Environ Contam Toxicol 70:248-254

Neher DA (1999) Soil community composition and ecosystem processes: comparing agricultural ecosystems with natural ecosystems. Agroforest Syst 45:159-185

OECD 207 (1984) OECD Guidelines for the testing of chemicals/ section 2: effects on biotic systems, Test No. 207: earthworm, acute toxicity tests. Organization for Economic Co-operation and Development, Paris, France, pp 1-9

OECD 208 (2006) OECD Guidelines for the testing of chemicals/ section 2: effects on biotic systems, Test No. 208: terrestrial plant test: seedling emergence and seedling growth test. Organization for Economic Co-operation and Development, Paris, France, pp 1-17

Pascual JA, Ayuso M, García C, Hernández T (1997) Characterization of urban wastes according to fertility and phytotoxicity parameters. Waste Manage Res 15:103-112

Piearce TG, Budd T, Hayhoe JM, Sleep D, Clasper PJ (2003) Earthworms of a land restoration site treated with paper mill sludge. Pedobiologia 47:792-795

Real Decreto 2994/1982, de 15 de octubre, sobre restauración de espacio natural afectado por actividades mineras. Ministerio de Industria y Energía (BOE número 274 de 15/11/1982).

Ros M, Hernández MT, García C (2003) Bioremediation of soil degraded by sewage sludge: effects on soil properties and erosion losses. Environ Manage 31:741-747

Rovira P, Vallejo R (2002) Labile and recalcitrant pools of carbon and nitrogen in organic matter decomposing at different depths in soil: an acid hydrolysis approach. Geoderma 107: 109-141

Scott-Fordsmand JJ, Krogh PH (2004) The influence of application form on the toxicity of nonylphenol to Folsomia fimetaria (Collembola: Isotomidae). Ecotoxicol Environ Saf 58:294299

Seniczak S, Klimek A, Kaczmarek S (1994) The mites (Acari) of an old Scots pine forest polluted by a nitrogen fertilizer factory at Wloclawek (Poland). II: Litter/soil fauna. Zool Beitr NF 35: $199-216$

Sort X, Alcañiz JM (1996) Contribution of sewage sludge to erosion control in the rehabilitation of limestone quarries. Land Degrad Dev 7:69-76 
Stenberg B, Johansson M, Pell M, Sjodahl-Svensson K, Stenstrom J, Torstensson L (1998) Microbial biomass and activities in soil as affected by frozen and cold storage. Soil Biol Biochem 30: 393-402

US EPA (1995) Process design manual: land application of sewage sludge and domestic septage. EPA/625/R-95/001. United States Environmental Protection Agency, Office of Research and Development, Washington, USA, p 301
Vance ED, Brookes PC, Jenkinson DS (1987) An extraction method for measuring soil microbial biomass-C. Soil Biol Biochem 19:703-707

Zmora-Nahum S, Markovitz O, Tarchitzky J, Chen Y (2005) Dissolved organic carbon (DOC) as a parameter of compost maturity. Soil Biol Biochem 37:2109-2116

Zucconi F, Pera A, Forte M, de Bertoldi M (1981) Evaluating toxicity of immature compost. BioCycle 22:54-57 